\title{
Complement 1q protects MRL/lpr mice against lupus nephritis via inhibiting the nuclear factor- $\kappa B$ pathway
}

\author{
JUANJUAN SUN, SHUXIA GUO, FUKUN NIU, DEFENG LIU and YAN ZHUANG \\ Department of Nephrology, Linyi Central Hospital, Linyi, Shandong 276400, P.R. China
}

Received January 21, 2020; Accepted August 26, 2020

DOI: $10.3892 / \mathrm{mmr} .2020 .11588$

\begin{abstract}
Lupus nephritis (LN) is a kidney disorder that is a critical cause of mortality in patients with systemic lupus erythematosus. The present study aimed to explore the protective role of complement component $1 \mathrm{q}(\mathrm{Clq})$ on $\mathrm{LN}$ and the underlying mechanism involving the nuclear factor (NF)- $\mathrm{KB}$ singling pathway. MRL/lpr mice served as the $\mathrm{LN}$ mouse model, and pcDNA-Clq was injected into $\mathrm{LN}$ mice to determine the role of Clq. Clq mRNA expression was detected using reverse transcription-quantitative PCR. Urine protein and blood urea nitrogen (BUN) levels were measured, and the histological damage index was determined using H\&E staining. ELISA was used to measure the levels of tumor necrosis factor- $\alpha$ (TNF- $\alpha$ ), interleukin (IL)-1 $\beta$, IL-6, anti-Clq and anti-double stranded DNA (dsDNA). CD68- and Ki67-positivity were detected using immunofluorescence, and NF- $\mathrm{\kappa B}$-related protein expression was examined using western blotting. Clq mRNA expression was downregulated in renal tissues of $\mathrm{LN}$ mice. Overexpression of $\mathrm{Clq}$ decreased urine protein, BUN levels and the histological damage index in LN mice. The levels of TNF- $\alpha$, IL-1 $\beta$, IL-6, anti-Clq and anti-dsDNA in renal tissues of LN mice were also reduced after pcDNA-Clq treatment. Additionally, overexpression of C1q decreased the CD68- and Ki67-positivity in glomeruli and attenuated the expression of NF- $\kappa \mathrm{B}-$ related proteins. Phorbol 12-myristate 13-acetate, an NF- $\mathrm{BB}$ pathway activator, reversed the inhibitory effect of Clq on inflammation, macrophage infiltration and mesangial cell (MC) proliferation in renal tissues of LN mice. Thus, it was demonstrated that $\mathrm{C} 1 \mathrm{q}$ ameliorated inflammation and macrophage infiltration and decreased MC proliferation in renal tissues of $\mathrm{LN}$ mice by inhibiting the NF- $\mathrm{KB}$ pathway.
\end{abstract}

Correspondence to: Dr Yan Zhuang, Department of Nephrology, Linyi Central Hospital, 17 Health Road, Yishui, Linyi, Shandong 276400, P.R. China

E-mail: zhuangyan1680@163.com

Key words: complement 1q, MRL/lpr mice, lupus nephritis, inflammation, nuclear factor- $\kappa \mathrm{B}$ pathway

\section{Introduction}

Lupus nephritis (LN) is a chronic and complex kidney disease (1) that is a frequent complication of systemic lupus erythematosus (2) and is usually associated with inflammatory cell infiltration and immune complex deposition in renal tissues (3). $\mathrm{LN}$ is clinically evident in $\sim 50 \%$ of patients with systemic lupus erythematosus (4). In LN, ICs initiate the synthesis of various proinflammatory cytokines, such as tumor necrosis factor- $\alpha$ (TNF- $\alpha$ ), interleukin (IL)- $1 \beta$ and IL-6, resulting in cellular infiltration and renal injury (5). The involvement of LN significantly increases patient morbidity and mortality rates (6). Patients with $\mathrm{LN}$ have a higher standardized mortality ratio (6-6.8 vs. 2.4) and lower survival rates compared with patients with systemic lupus erythematosus who do not have LN (7). LN pathogenesis is complex, and some patients with LN may develop end-stage renal disease (8). Therefore, it is essential to explore new approaches for the treatment of $\mathrm{LN}$.

Complement component $1 \mathrm{q}(\mathrm{Clq})$ is a subcomponent of the $\mathrm{C} 1$ complex, which participates in the classical pathway of complement activation (9). Clq has numerous functions, including recognition of ICs and activation of the complement system (10). Previous studies have examined the relationship between LN and anti-Clq. For example, a significantly negative correlation between C1q and anti-Clq was found in patients with LN (11). Anti-Clq was also associated with proteinuria and renal activity score in patients with $\mathrm{LN}$, and could serve as a potential biomarker of LN (12). In addition, high anti-Clq antibody titers are present in the blood of patients with $\mathrm{LN}$, and the level of anti-Clq is related with disease progression (13). Anti-Clq has adequate specificity and sensitivity for $\mathrm{LN}$ diagnosis and can be used to evaluate renal activity (14); however, the underlying mechanism of Clq in the regulation of $\mathrm{LN}$ remains poorly understood.

Nuclear factor (NF)- $\mathrm{kB}$ not only participates in innate and adaptive immunity (15), but also is considered to be a proinflammatory transcription factor (16). The NF- $\kappa B$ pathway is related to several pathological processes in the kidneys, including immune response, inflammation and mesangial cell (MC) proliferation (17-19). Deletion of NF- $\mathrm{kB}$ p65 was found to alleviate $\mathrm{LN}$ in mice (20). In $\mathrm{LN}$, inhibition of the NF- $\mathrm{KB}$ pathway suppressed the inflammatory response (21), and blocking this pathway may decrease macrophage chemotaxis and MC proliferation (22). Nevertheless, the potential regulatory 
mechanism of $\mathrm{Clq}$ in relation to the $\mathrm{NF}-\kappa \mathrm{B}$ pathway in $\mathrm{LN}$ is still unknown.

In the present study, C1q expression in $\mathrm{LN}$ mice was evaluated and the regulatory effects of $\mathrm{C} 1 \mathrm{q}$ on renal injury, inflammation, macrophage infiltration and MC proliferation was explored. The function of $\mathrm{Clq}$ in regulating $\mathrm{NF}-\kappa \mathrm{B}$ pathway activity in LN mice was also explored. These results may suggest a potential therapeutic target for LN.

\section{Materials and methods}

Animals. In total, 60 male MRL/lpr mice (used as an LN mouse model) and 15 C57BL/6 mice (age, 3 months; body weight, 18-22 g) were purchased from Shanghai SLAC Laboratory Animal Co., Ltd. Mice were maintained at $23-25^{\circ} \mathrm{C}$ and $50-55 \%$ relative humidity, and kept under a $12 \mathrm{~h} / 12 \mathrm{~h}$ light/dark cycle with ad libitum access to food and water. The present study was performed with the approval of The Animal Ethics Committee of Linyi Central Hospital (Linyi, China).

Experimental design. pcDNA-C1q and pcDNA-negative control (NC) were obtained from Sangon Biotech Co., Ltd. After one week of adjustment, $\mathrm{LN}$ mice were divided into pc-NC, pcDNA-C1q and Sham groups, which were injected intraperitoneally with $1 \mathrm{mg} / \mathrm{kg}$ pc-NC, $1 \mathrm{mg} / \mathrm{kg}$ pcDNA-Clq or an equivalent quantity of normal saline, respectively (15 mice in each group). C57BL/6 mice without treatment acted as the BLANK group. In addition, $\mathrm{LN}$ mice in the $\mathrm{C} 1 \mathrm{q}+$ Phorbol 12-myristate 13-acetate (PMA) group were injected intraperitoneally with $1 \mathrm{mg} / \mathrm{kg}$ pcDNA-Clq and treated with PMA (25 nM; Sigma-Aldrich; Merck KGaA).

Reverse transcription-quantitative $(R T-q) P C R$. Total RNA was extracted from renal tissues using TRIzol ${ }^{\circledR}$ reagent (Invitrogen; Thermo Fisher Scientific, Inc.) and reverse transcribed into cDNA using the PrimeScript RT reagent kit (Takara Bio, Inc.). The reaction mixtures were incubated at $37^{\circ} \mathrm{C}$ for $60 \mathrm{~min}$, $95^{\circ} \mathrm{C}$ for $5 \mathrm{~min}$ and then held at $4^{\circ} \mathrm{C}$. miScript SYBR Green PCR kit (Qiagen, Inc.) was used to conduct qPCR. The qPCR reaction was performed on the ABI 7500HT Fast Real-Time PCR system (Applied Biosystems; Thermo Fisher Scientific, Inc.) with the following conditions: $95^{\circ} \mathrm{C}$ for $3 \mathrm{~min}$, followed by 40 cycles of $95^{\circ} \mathrm{C}$ for $15 \mathrm{sec}$ and $60^{\circ} \mathrm{C}$ for $30 \mathrm{sec}$, and a final extension step at $72^{\circ} \mathrm{C}$ for $10 \mathrm{~min}$. Relative expression was calculated using the $2^{-\Delta \Delta \mathrm{Cq}}$ method (23). GAPDH was used for normalization. Primer sequences are shown in Table I.

Evaluation of renal function. The 24-h urine protein excretion was measured once every 2 weeks using Multistix 10SG reagent strips (Siemens Healthineers). After 4 weeks continuous treatment, mice were anesthetized by intraperitoneal administration of $50 \mathrm{mg} / \mathrm{kg}$ pentobarbital sodium and sacrificed by cervical dislocation. Blood samples and renal tissues were collected for future experiments. Blood urea nitrogen (BUN) levels were measured using an automatic biochemical analyzer (Hitachi, Ltd.).

$H \&$ Estaining. Renal tissues were fixed in $4 \%$ paraformaldehyde for $24 \mathrm{~h}$ at $37^{\circ} \mathrm{C}$, embedded in paraffin, cut into $4-\mu \mathrm{m}$ thick sections, dewaxed in xylene and rehydrated with $90 \%$ ethanol
Table I. Primer sequences used in reverse transcriptionquantitative PCR.

\begin{tabular}{ll}
\hline Primer & \multicolumn{1}{c}{ Sequences $\left(5^{\prime} \rightarrow 3^{\prime}\right)$} \\
\hline Complement 1q & F: GAAACAATGGGAACAATGGAG \\
& R: TGCTGAAGGTGAAGAAATACA \\
GAPDH & F: ACACCTTCTACAATGAGCTG \\
& R: CTGCTTGCTGATCCACATCT \\
\hline
\end{tabular}

F, forward; R, reverse.

at $37^{\circ} \mathrm{C}$. Sections were then stained with hematoxylin for $2 \mathrm{~min}$ and eosin for $2 \mathrm{~min}$ at $37^{\circ} \mathrm{C}$. Using light microscopy, the degree of histological damage in renal tissues was observed (magnification, x400). The histological damage index of glomerulus was graded on a scale of 0-3 as previously described by Muraoka et al (24), where $0=$ normal, $1=$ mild (cell proliferation and/or cell infiltration), $2=$ moderate (cell proliferation and/or cell infiltration with membrane proliferation) and $3=$ severe (cell proliferation and/or cell infiltration, membrane proliferation and crescent formation and/or hyalinosis).

Western blotting. Renal tissues were lysed using ice-cold RIPA lysis buffer (Beyotime Institute of Biotechnology) to obtain total protein. The concentration of total protein was detected using a bicinchoninic acid protein concentration assay kit (Cell Signaling Technology, Inc.). Total protein (60 $\mu \mathrm{g} / \mathrm{lane})$ was separated using sodium dodecyl sulphate polyacrylamide gel electrophoresis (10\% separating gum and 5\% concentrating gum), and subsequently transferred onto a polyvinylidene fluoride membrane. The membranes were blocked with $5 \%$ skimmed milk for $1 \mathrm{~h}$ at $37^{\circ} \mathrm{C}$. Then, membranes were incubated with primary antibodies overnight at $4^{\circ} \mathrm{C}$. The antibodies used were as follows: Anti-IкB $\alpha$ (1:1,000; cat. no. 9242), anti-phos-

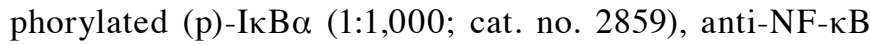
p65 (1:1,000; cat. no. 8242) and anti-p-NF-кB p65 (1:1,000; cat. no. 8214) (all CST Biological Reagents Co., Ltd.). Next, membranes were incubated with HRP-labelled goat anti-rabbit IgG (1:2,000; cat. no. I5006MSDS) and HRP-labelled goat anti-mouse IgG secondary antibodies (1:4,000; cat. no. 12-349; both purchased from Sigma-Aldrich; Merck KGaA) for $1 \mathrm{~h}$ at $25^{\circ} \mathrm{C}$. Finally, protein bands were visualized using enhanced chemiluminescence exposure solution (Invitrogen; Thermo Fisher Scientific, Inc.) and semi-quantified using Quantity One 1-D software (version 4.62; Bio-Rad Laboratories, Inc.). GAPDH (1:1,000; cat. no. 100242-MM05; Sino Biological) was used as a loading control.

ELISA. Renal tissue homogenate from each group was centrifuged at $3,000 \mathrm{x}$ g at $4^{\circ} \mathrm{C}$ for $10 \mathrm{~min}$ and the resulting supernatant was collected. Then, the levels of TNF- $\alpha$ (cat. no. ab236712), IL-1 $\beta$ (cat. no. ab197742), IL-6 (cat. no. ab100713) and anti-Clq (cat. no. ab170246) were measured using ELISA kits (all purchased from Abcam). The level of anti-dsDNA was measured by the automated Alegria ${ }^{\circledR}$ ELISA reader (Orgentec Diagnostika 
A

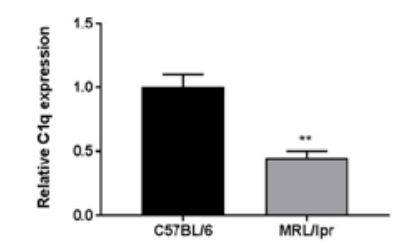

D

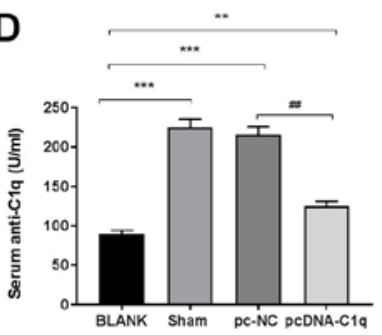

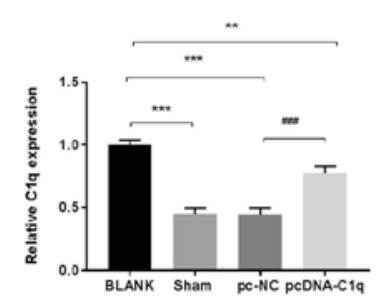

E

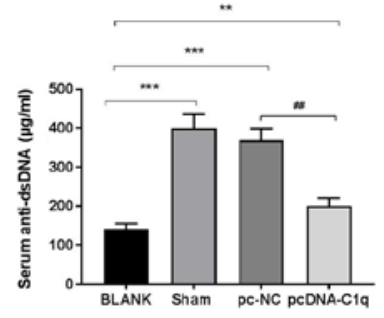

B

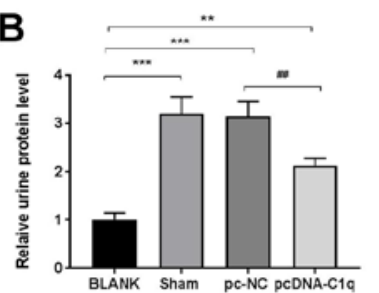

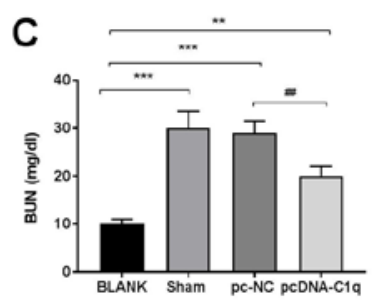

pc-NC

PCDNA-C1q
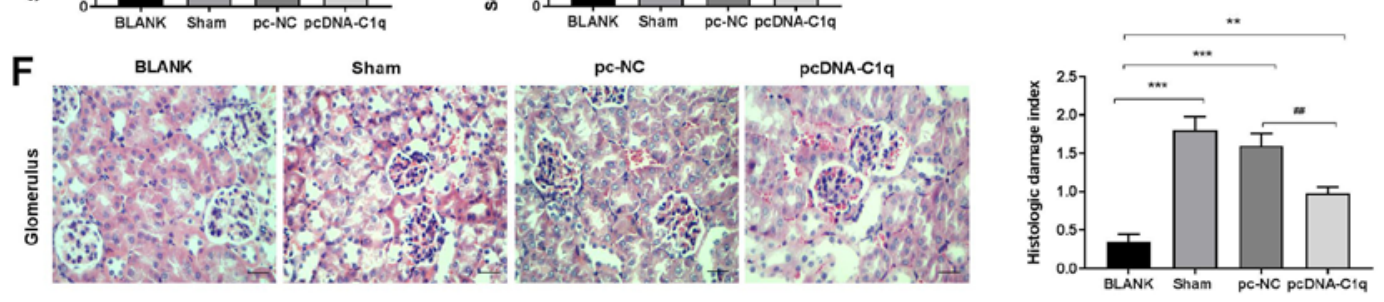

Figure 1. Overexpression of $\mathrm{Clq}$ alleviates renal injury in LN mice. (A) mRNA expression of Clq in renal tissues was detected using reverse transcription-quantitative PCR. (B) Relative level of urine protein at $24 \mathrm{~h}$. (C) Levels of serum BUN. Levels of serum (D) anti-Clq and (E) anti-dsDNA were measured using ELISA. (F) The histological damage index of glomerulus was determined using H\&E staining. There were 15 mice in each group and the experiments were repeated three times. ${ }^{* *} \mathrm{P}<0.01,{ }^{* * *} \mathrm{P}<0.001$ vs. C57BL/6 or BLANK; ${ }^{\# \#} \mathrm{P}<0.01,{ }^{\# \# /} \mathrm{P}<0.001$ vs. pc-NC. C1q, complement component 1q; LN, lupus nephritis; BUN, blood urea nitrogen; NC, negative control; dsDNA, double stranded DNA; BLANK, C57BL/6 mice without treatment; Sham, LN mice injected intraperitoneally with normal saline; pc-NC, LN mice injected intraperitoneally with pc-NC; pcDNA-C1q, LN mice injected intraperitoneally with pcDNA-C1q.

A

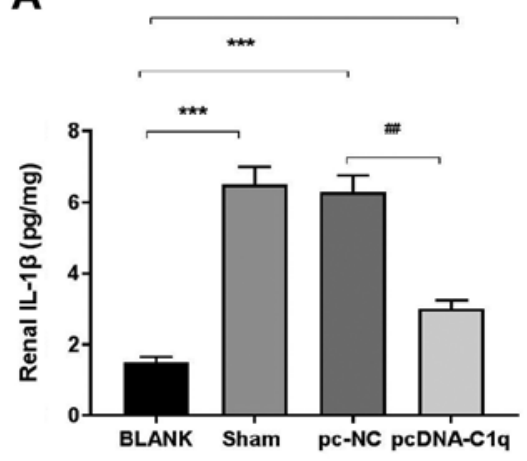

B

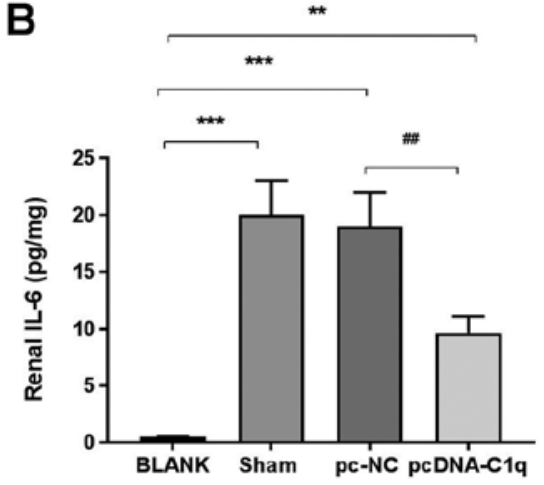

C

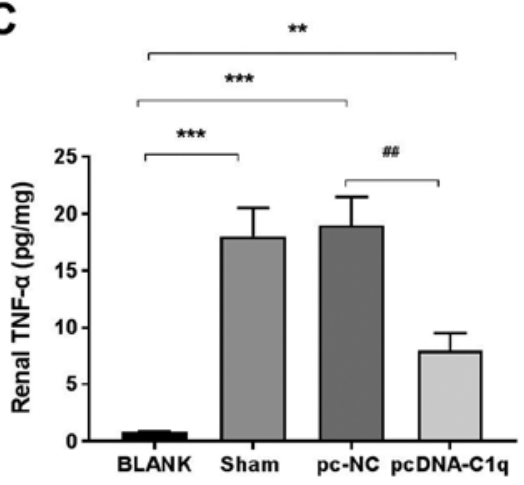

Figure 2. Overexpression of Clq attenuates renal inflammation in LN mice. Levels of (A) IL-1 $\beta$, (B) IL-6 and (C) TNF- $\alpha$ in renal tissues were measured using ELISA. There were 15 mice in each group and the experiments were repeated three times. ${ }^{* * *} \mathrm{P}<0.01,{ }^{* * * *} \mathrm{P}<0.001$ vs. BLANK; ${ }^{\# \#} \mathrm{P}<0.01$ vs. pc-NC. C1q, complement component 1q; LN, lupus nephritis; IL, interleukin; BLANK, C57BL/6 mice without treatment; Sham, LN mice injected intraperitoneally with normal saline; pc-NC, LN mice injected intraperitoneally with pc-NC; pcDNA-Clq, LN mice injected intraperitoneally with pcDNA-Clq.

$\mathrm{GmbH}$ ), according to the manufacturer's instructions. The absorbance of each well was measured at $450 \mathrm{~nm}$ using an enzyme mark instrument (Thermo Fisher Scientific, Inc.).

Immunofluorescence staining. Frozen glomeruli sections $(5 \mu \mathrm{m})$ were dried for $15 \mathrm{~min}$ at $25^{\circ} \mathrm{C}$. After rinsing three times, sections were blocked in PBS containing $10 \%$ goat serum (cat. no. 16210064; Thermo Fisher Scientific, Inc.) for $1 \mathrm{~h}$ at $25^{\circ} \mathrm{C}$. Glomeruli sections were incubated with anti-CD68 antibody ( $1 \mu \mathrm{g} / \mathrm{ml}$; cat. no. ab201340) or anti-Ki67 antibody ( $1 \mu \mathrm{g} / \mathrm{ml}$; cat. no. ab15580; both Abcam) overnight at $4^{\circ} \mathrm{C}$, followed by incubation with Alexa Fluor 488-conjugated goat anti-rabbit IgG (1:500; cat. no. ab150077; Abcam) for $1 \mathrm{~h}$ at $25^{\circ} \mathrm{C}$. Glomeruli sections were counterstained with DAPI $(2.5 \mathrm{ng} / \mu \mathrm{l})$ at $25^{\circ} \mathrm{C}$ for $1 \mathrm{~h}$, and the percentages of CD68- and Ki67-positivity were detected using immunofluorescence microscopy (magnification, $\mathrm{x} 400$; Olympus Corporation). The CellProfiler 4.0 software (www.cellprofiler.org) was used to quantify the DAPI intensity at the peri-nucleolar region of $\sim 100$ individual cells.

Statistical analysis. Statistical analysis was performed with SPSS 23.0 (IBM Corp.). Data were presented as the mean \pm SD. All experiments were repeated three times. Differences among multiple groups were analyzed using 
A
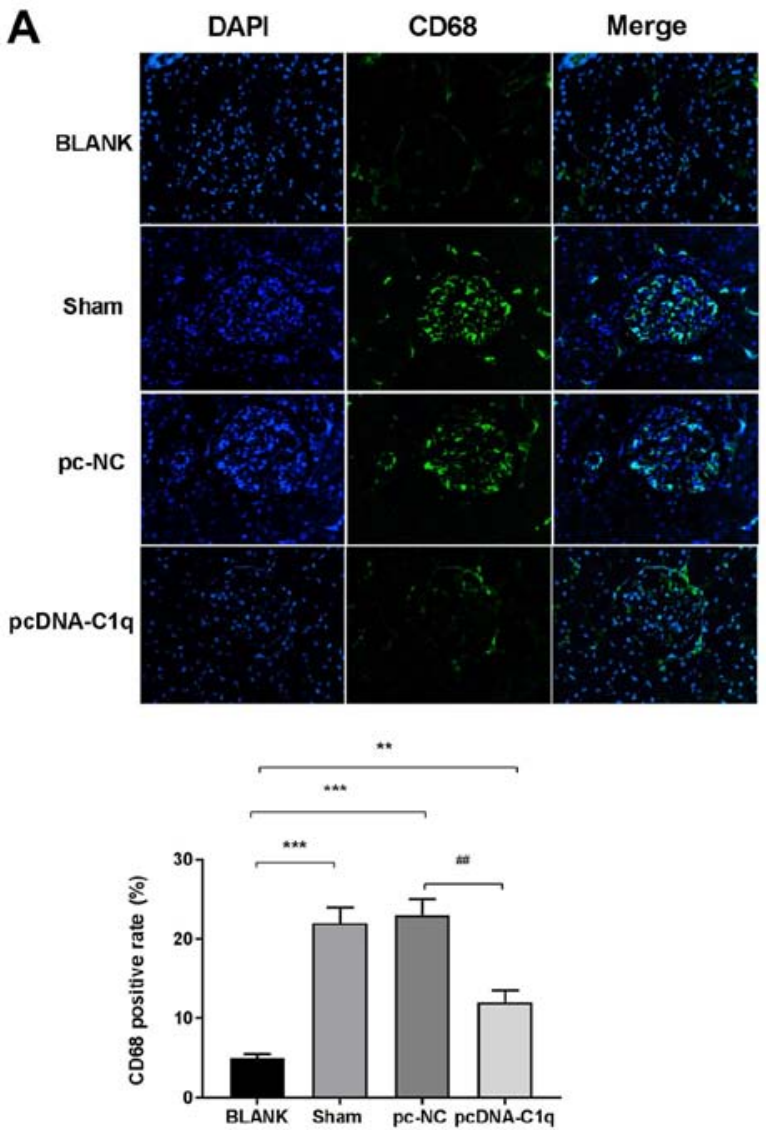

B
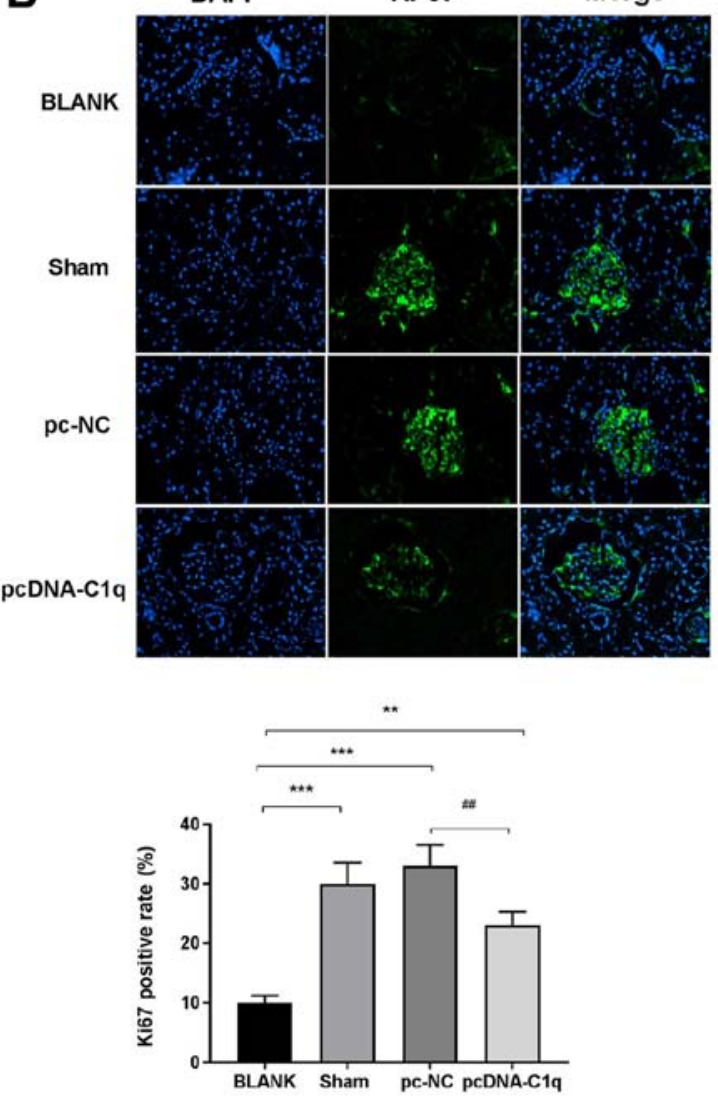

Figure 3. Overexpression of C1q inhibits macrophage infiltration and mesangial cell proliferation in renal tissues of LN mice. (A) CD68- and (B) Ki67-positivity were detected using immunofluorescence staining (magnification, $\mathrm{x} 400$ ). There were 15 mice in each group and the experiments were repeated three times. ${ }^{* *} \mathrm{P}<0.01,{ }^{* * * *} \mathrm{P}<0.001$ vs. BLANK; ${ }^{\# / P} \mathrm{P}<0.01$ vs. pc-NC. Clq, complement component 1q; LN, lupus nephritis; BLANK, C57BL/6 mice without treatment; Sham, LN mice injected intraperitoneally with normal saline; pc-NC, LN mice injected intraperitoneally with pc-NC; pcDNA-Clq, LN mice injected intraperitoneally with pcDNA-Clq.
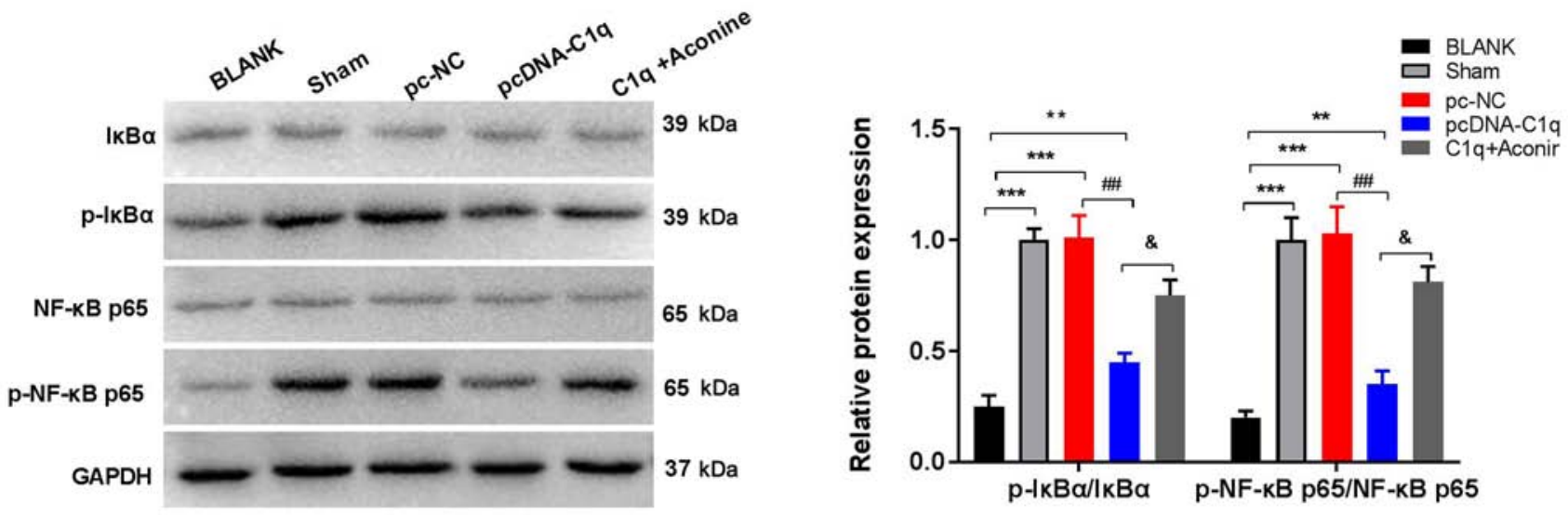

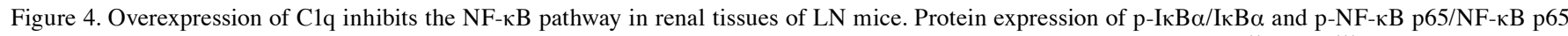
was measured using western blot analysis. There were 15 mice in each group and the experiments were repeated three times. ${ }^{* *} \mathrm{P}<0.01,{ }^{* * *} \mathrm{P}<0.001 \mathrm{vs}$. BLANK; ${ }^{\# \#} \mathrm{P}<0.01$ vs. pc-NC; ${ }^{~} \mathrm{P}<0.05$ vs. pcDNA-C1q. C1q, complement component 1q; LN, lupus nephritis; p, phosphorylated; PMA, phorbol 12-myristate 13-acetate; BLANK, C57BL/6 mice without treatment; Sham, LN mice injected intraperitoneally with normal saline; pc-NC, LN mice injected intraperitoneally with pc-NC; pcDNA-C1q, LN mice injected intraperitoneally with pcDNA-C1q; Clq + PMA, LN mice were injected intraperitoneally with pcDNA-Clq and treated with PMA.

one-way ANOVA followed by Tukey's multiple comparisons test. Data of two groups were assessed using unpaired Student's t-test. $\mathrm{P}<0.05$ was considered to indicate a statistically significant difference.

\section{Results}

Overexpression of Clq alleviates renal injury in $L N$ mice. Analysis using RT-qPCR indicated that Clq mRNA 
A

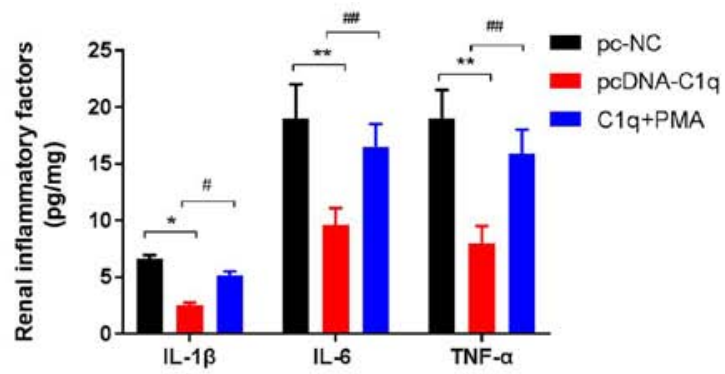

B
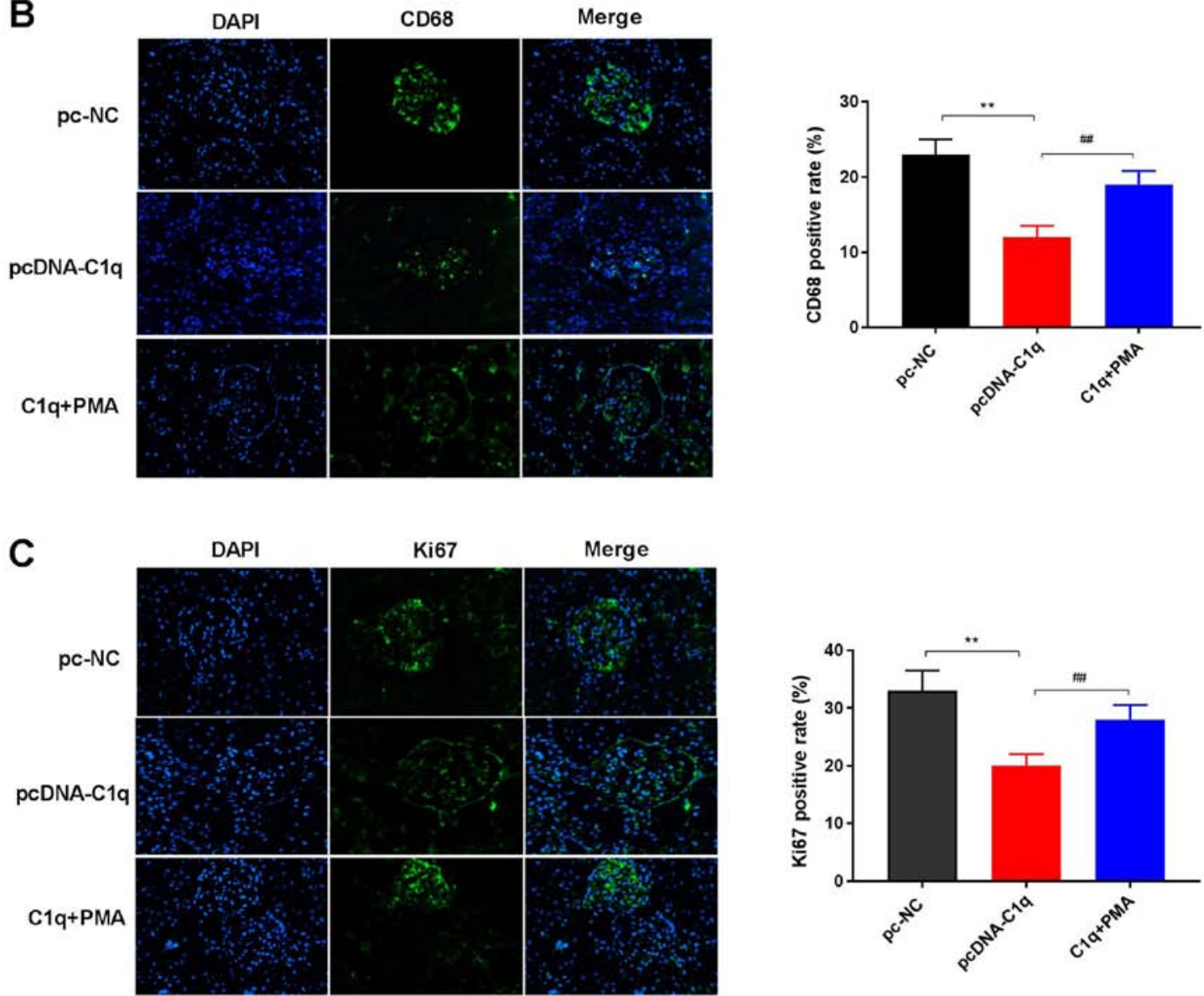

Figure 5. Overexpression of C1q ameliorates renal injury in LN mice via inhibiting the NF-kB pathway. (A) Levels of TNF- $\alpha$, IL-6 and IL-1 $\beta$ in renal tissues were measured using ELISA. (B) CD68- (C) Ki67-positivity were detected using immunofluorescence staining (magnification, $\mathrm{x} 400$ ). There were 15 mice in each group and the experiments were repeated three times. ${ }^{*} \mathrm{P}<0.05,{ }^{* *} \mathrm{P}<0.01$ vs. pc-NC; ${ }^{*} \mathrm{P}<0.05,{ }^{\# \#} \mathrm{P}<0.01$ vs. pcDNA-Clq. Clq, complement component 1q; LN, lupus nephritis; IL, interleukin; PMA, phorbol 12-myristate 13-acetate; pc-NC, LN mice injected intraperitoneally with pc-NC; pcDNA-Clq, LN mice injected intraperitoneally with pcDNA-C1q; Clq + PMA, LN mice were injected intraperitoneally with pcDNA-Clq and treated with PMA.

expression was decreased in MRL/lpr mice (LN mice) compared with C57BL/6 mice. C1q-overexpression was induced by transfecting pcDNA-C1q (Fig. 1A), and the urine protein and BUN levels were examined. Compared with the BLANK group, urine protein and BUN levels were significantly increased in the Sham group, whereas transfection of pcDNA-Clq significantly decreased these levels $(\mathrm{P}<0.01$; Fig. $1 \mathrm{~B}$ and $\mathrm{C})$. ELISA analysis showed that the levels of serum anti-C1q and anti-dsDNA were significantly elevated in the Sham group compared with the BLANK group. Overexpression of C1q reduced the levels of serum anti-Clq and anti-dsDNA compared with the pc-NC group (Fig. 1D and E). Compared with the BLANK group, $\mathrm{H} \& \mathrm{E}$ staining showed a higher histological damage index of glomeruli in the Sham group. Additionally, the histological damage index was lower in the pcDNA-Clq group compared with that in the pc-NC group (Fig. 1F). These results suggested that $\mathrm{C} 1 \mathrm{q}$ overexpression may attenuate renal injury in $\mathrm{LN}$ mice.

Overexpression of $\mathrm{Clq}$ attenuates renal inflammation in $L N$ mice. ELISA analysis revealed that the levels of TNF- $\alpha$, IL- 6 and IL-1 $\beta$ in renal tissues in the Sham group were markedly increased compared with those in the BLANK group. Overexpression of Clq significantly reduced the levels of TNF- $\alpha$, IL- 6 and IL-1 $\beta$ in renal tissues in the pcDNA-Clq compared with the pc-NC group (Fig. 2A-C). Overall, these results indicated that $\mathrm{Clq}$ overexpression may alleviate the renal inflammation in $\mathrm{LN}$ mice. 
Overexpression of $\mathrm{Clq}$ reduces macrophage infiltration and $M C$ proliferation in renal tissues of $L N$ mice. To investigate the effect of $\mathrm{Clq}$ on macrophage infiltration and the proliferation of MCs in the renal tissues of LN mice, the percentages of CD68- and Ki67-positivity were measured using immunofluorescence staining. The percentage of CD68-positivity in Sham group renal tissues was higher compared with that of the BLANK group. Furthermore, compared with the Sham group, this percentage was decreased in the pcDNA-C1q group (Fig. 3A). In addition, with the BLANK group, the percentage of Ki67-positivity in renal tissues was increased in the Sham group and was decreased by Clq-overexpression (Fig. 3B). Taken together, Clq overexpression may decrease macrophage infiltration and $\mathrm{MC}$ proliferation in renal tissues of $\mathrm{LN}$ mice.

Overexpression of Clq inhibits the $N F-\kappa B$ pathway in the renal tissues of $L N$ mice. To evaluate the effect of Clq-overexpression on the NF- $\mathrm{KB}$ pathway in $\mathrm{LN}$ mouse renal tissues, the expression of NF- $\mathrm{KB}$-related proteins was measured via western blotting. Compared with the BLANK group, the protein

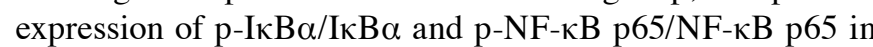
renal tissues was significantly increased in the Sham group. These levels in renal tissues were significantly decreased in the pcDNA-Clq group compared with the Sham group. PMA, an activator of the NF- $\mathrm{kB}$ pathway (25), was injected into the pcDNA-Clq-treated LN mice. Consequently, the inhibitory effect of Clq on the NF-kB pathway was attenuated by PMA compared with the pcDNA-Clq group (Fig. 4). These results demonstrated that $\mathrm{Clq}$ overexpression may inhibit the NF- $\mathrm{KB}$ pathway in the renal tissues of $\mathrm{LN}$ mice.

Overexpression of Clq ameliorates renal injury in $L N$ mice via inhibiting the $N F-\kappa B$ pathway. PMA was administered to $\mathrm{LN}$ mice, and the levels of renal inflammatory factors were measured. The results showed that overexpression of $\mathrm{Clq}$ significantly decreased the levels of TNF- $\alpha$, IL- $1 \beta$ and IL-6 in the renal tissues of LN mice (Fig. 5A). In addition, immunofluorescence staining demonstrated that the percentages of CD68- and Ki67-positivity in renal tissues were decreased in the pcDNA-Clq group compared with the pc-NC group (Fig. 5B and C). Moreover, PMA attenuated the effects of Clq on inflammatory factors and percentages of CD68- and Ki67-positivity in LN mice renal tissues (Fig. 5A-C). Overall this indicated that $\mathrm{Clq}$ overexpression may ameliorate renal injury by inhibiting the NF-kB pathway in $\mathrm{LN}$ mice.

\section{Discussion}

The MRL/lpr mouse model is frequently recognized as a suitable model of human $\mathrm{LN}(26,27)$. In the present study, Clq expression was decreased in LN mice. The 24-h urine protein and BUN levels are reliable measures of renal function in patients with $\mathrm{LN}(28,29)$, and, in the present study, these levels were decreased by Clq-overexpression in $\mathrm{LN}$ mice. Anti-Clq and anti-dsDNA are valuable biological markers for the prediction of human $\mathrm{LN}(30,31)$. It was shown in the present study that transfection of pcDNA-Clq significantly reduced the levels of serum anti-Clq and anti-dsDNA in LN mice. In addition, overexpression of $\mathrm{Clq}$ also decreased the histological damage index of glomeruli in LN mice. Taken together, these results suggested that $\mathrm{Clq}$ alleviates renal injury in $\mathrm{LN}$ mice through improving renal function and attenuating histological damage.

Proinflammatory cytokines play critical roles in the occurrence and developmental process of $\mathrm{LN}(32,33)$. For example, nucleotide-binding oligomerization domain-containing protein 2 was found to participate in $\mathrm{LN}$ pathogenesis through promoting the release of proinflammatory cytokines (34). Upregulation of microRNA-146a alleviated $\mathrm{LN}$ in patients via suppressing the gene expression of TNF- $\alpha$, IL-1 $\beta$ and IL-6 (35). In the present study, overexpression of Clq significantly decreased the levels of proinflammatory cytokines in the renal tissues of LN mice. CD68-positivity is a macrophage marker in renal diseases (36). Macrophage infiltration in renal tissues induced by $\mathrm{T}$ cells is related to podocyte injury in patients with LN (37). Ki67 is a nuclear protein associated with the cell cycle and is used as a marker for MC proliferation in glomeruli (38). Normal MC proliferation is involved in maintaining glomerular function and structure (39). The results of the present study demonstrated that $\mathrm{Clq}$-overexpression significantly reduced macrophage infiltration and MC proliferation in the renal tissues of $\mathrm{LN}$ mice. Together, these data indicated that $\mathrm{Clq}$ protected against LN by decreasing inflammation, macrophage infiltration and MC proliferation in renal tissues.

Previous research found that the NF- $\kappa \mathrm{B}$ pathway participates in $\mathrm{LN}$ progression $(40,41)$. In the present study, the expression of NF-kB-related proteins in the renal tissues of LN mice was significantly decreased by treatment with pcDNA-Clq, indicating that Clq inhibited the NF- $\kappa B$ pathway in these tissues. The NF- $\kappa B$ pathway was found to play a role in $\mathrm{LN}$ inflammation, and was ameliorated by demethylzeylasteral

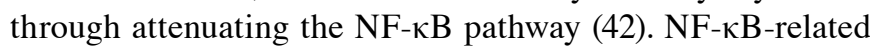
proteins are also related to the macrophage infiltration and MC proliferation in renal diseases. Curcumin alleviated macrophage infiltration of diabetic nephropathy by inhibiting NF- $\kappa B$ activation (43). Resveratrol reduced renal MC proliferation in diabetic nephropathy via downregulating the expression of NF- $\mathrm{kB}$-related proteins (44). In the present study, it was found that overexpression of Clq decreased inflammation, macrophage infiltration and $\mathrm{MC}$ proliferation through inhibiting the NF- $\mathrm{\kappa B}$ pathway in the renal tissues of $\mathrm{LN}$ mice. To further confirm this result, $\mathrm{LN}$ mice were treated with PMA, an NF- $\mathrm{BB}$ pathway activator (45). The results showed that PMA effectively reversed the inhibitory effect of Clq on inflammation, macrophage infiltration and MC proliferation in the renal tissues of LN mice. Taken together, it was demonstrated that Clq may protect against $\mathrm{LN}$ through inhibiting the NF- $\kappa B$ pathway.

The present study has some limitations. Firstly, only glomerular nephritis in mice was analyzed. Interstitial nephritis, another type of renal inflammation in LN mice (46), may more comprehensively reflect the histopathological changes in LN. Secondly, IFN- $\gamma$, a key regulator in renal tissues, was not detected. IFN- $\gamma$ plays a role in the perpetuation of local inflammatory processes in the kidney by the activation of monocytes, macrophages or renal resident cells. The expression of IFN- $\gamma$ in renal tissues may better reflect the inflammatory changes in LN. Finally, the detailed mechanism of action of $\mathrm{Clq}$ in $\mathrm{LN}$ remains to be studied. Further in vitro 
experiments are needed to identify the regulatory mechanism of C1q in the development of LN.

In summary, C1q expression was decreased in the renal tissues of LN mice. Overexpression of C1q alleviated inflammation and macrophage infiltration and inhibited MC proliferation in these tissues. The protective effect of $\mathrm{Clq}$ on LN was closely associated with the suppression of the NF- $\kappa \mathrm{B}$ pathway. Therefore, $\mathrm{Clq}$ may be a promising therapeutic target for $\mathrm{LN}$.

\section{Acknowledgements}

Not applicable.

\section{Funding}

No funding was received.

\section{Availability of data and materials}

The datasets used and/or analyzed during the current study are available from the corresponding author on reasonable request.

\section{Authors' contributions}

JS conceived and designed the study, performed the data analyses and wrote the manuscript. SG, FN and DL contributed to the conception of the study. JS, SG, FN and DL performed the experiments. YZ contributed to analysis and manuscript preparation. All authors have read and approved the final version of the manuscript.

\section{Ethics approval and consent to participate}

The present study was approved by The Ethics Committee of Linyi Central Hospital (approval no. 2020013; Linyi, China).

\section{Patient consent for publication}

Not applicable.

\section{Competing interests}

The authors declare that they have no competing interests

\section{References}

1. Davidson A, Aranow C and Mackay M: Lupus Nephritis: Challenges and progress. Curr Opin Rheumatol 31: 682-688, 2019.

2. Cameron JS: Lupus Nephritis. J Am Soc Nephrol 10: 413-424, 1999.

3. Faurschou M, Dreyer L, Kamper AL, Starklint H and Jacobsen S: Long-term mortality and renal outcome in a cohort of 100 patients with lupus nephritis. Arthritis Care Res (Hoboken) 62: 873-880. 2010.

4. Parikh SV, Almaani S, Brodsky S and Rovin BH: Update on lupus nephritis: Core curriculum 2020. Am J Kidney Dis 76: 265-281, 2020

5. Inoue A, Hasegawa H, Kohno M, Ito MR, Terada M, Imai T, Yoshie O, Nose M and Fujita S: Antagonist of fractalkine (CX3CL1) delays the initiation and ameliorates the progression of lupus nephritis in MRL/lpr mice. Arthritis Rheum 52: 1522-1533, 2005.
6. Mok CC, Kwok RC and Yip PS: Effect of renal disease on the standardized mortality ratio and life expectancy of patients with systemic lupus erythematosus. Arthritis Rheum 65: 2154-2160, 2013.

7. Almaani S, Meara A and Rovin BH: Update on lupus nephritis. Clin J Am Soc Nephrol 12: 825-835, 2017.

8. Houssiau FA and Ginzler EM: Current treatment of lupus nephritis. Lupus 17: 426-430, 2008.

9. Kishore U and Reid KBM: C1q: Structure, function, and receptors. Immunopharmacology 49: 159-170, 2000.

10. Liu G, Pang Y, Liu X and Li QW: Structure, distribution, classification, and function of $\mathrm{Clq}$ protein family: A review. Yi Chuan 35: 1072-1080, 2013 (In Chinese).

11. Zhang FC, Zhou B and Dong Y: The roles of complement 1q and anti-C1q autoantibodies in pathogenesis of lupus nephritis. Zhonghua Yi Xue Za Zhi 85: 955-959, 2005 (In Chinese).

12. Akhter E, Burlingame RW, Seaman AL, Magder L and Petri M: Anti-Clq antibodies have higher correlation with flares of lupus nephritis than other serum markers. Lupus 20: 1267-1274, 2011.

13. Sinico RA, Radice A, Ikehata M, Giammarresi G, Corace C, Arrigo G, Bollini B and Li Vecchi M: Anti-Clq autoantibodies in lupus nephritis: Prevalence and clinical significance. Ann N Y Acad Sci 1050: 193-200, 2005.

14. Yin Y, Wu X, Shan G and Zhang X: Diagnostic value of serum anti-Clq antibodies in patients with lupus nephritis: A meta-analysis. Lupus 21: 1088-1097, 2012.

15. Mankan AK, Lawless MW, Gray SG, Kelleher D and McManus R: $\mathrm{NF}-\kappa \mathrm{B}$ regulation: The nuclear response. J Cell Mol Med 13: 631-643. 2009.

16. Ruan Q and Chen YH: Nuclear factor- $\kappa \mathrm{B}$ in immunity and inflammation: The Treg and Th17 connection. Adv Exp Med Biol 946: 207-221, 2012.

17. Zhong J, Shi QQ, Zhu MM, Shen J, Wang HH, Ma D and Miao CH: MFHAS1 is associated with sepsis and stimulates TLR2/NF- $\mathrm{BB}$ signaling pathway following negative regulation. PLoS One 10: e0143662, 2015.

18. Zhou Y, Fang L, Jiang L, Wen P, Cao H, He W, Dai C and Yang J: Uric acid induces renal inflammation via activating tubular NF-кB signaling pathway. PLoS One 7: e39738, 2012

19. Xu F, Wang Y, Cui W, Yuan H, Sun J, Wu M, Guo Q, Kong L, Wu H and Miao L: Resveratrol prevention of diabetic nephropathy is associated with the suppression of renal inflammation and mesangial cell proliferation: Possible roles of Akt/NF-B Pathway. Int J Endocrinol 2014: 1-9, 2014.

20. Jiang X, Zhao X, Luo $\mathrm{H}$ and Zhu K: Therapeutic effect of polysaccharide of large yellow croaker swim bladder on lupus nephritis of mice. Nutrients 6: 1223-1235, 2014.

21. Jiang T, Tian F, Zheng H, Whitman SA, Lin Y, Zhang Z, Zhang N, and Zhang DD: Nrf2 suppresses lupus nephritis through inhibition of oxidative injury and the NF- $\mathrm{BB}$-mediated inflammatory response. Kidney Int 85: 333-343, 2014.

22. Sun F, Teng J, Yu P, Li W, Chang $\mathbf{J}$ and $\mathrm{Xu} \mathrm{H}$ : Involvement of TWEAK and the NF- $\kappa$ B signaling pathway in lupus nephritis. Exp Ther Med 15: 2611-2619, 2018.

23. Livak KJ and Schmittgen TD: Analysis of relative gene expression data using real-time quantitative PCR and the 2(-Delta Delta C(T)) method. Methods 25: 402-408, 2001.

24. Muraoka M, Hasegawa $H$, Kohno M, Inoue A, Miyazaki T, Terada M, Nose M and Yasukawa M: IK cytokine ameliorates the progression of lupus nephritis in MRL/lpr mice. Arthritis Rheum 54: 3591-3600, 2006.

25. Kong R, Kang OH, Seo YS, Zhou T, Kim SA, Shin DW and Kwon DY: MAPKs and NF- $\kappa$ B pathway inhibitory effect of bisdemethoxycurcumin on phorbol 12 myristate 13 acetate and A23187 induced inflammation in human mast cells. Mol Med Rep 17: 630-635, 2018.

26. Wang YY, Li HT, Lu Y, Jia XY, Li YL, Chen S, Chai JX, Zhang JJ, Liu D and Xie CH: Protective effects of glycyrrhizic acid against lupus nephritis in MRL/lpr mice. Nan Fang Yi Ke Da Xue Xue Bao 37: 957-961, 2017 (In Chinese).

27. Liu Z, Xue L, Liu Z, Huang J, Wen J, Hu J, Bo L and Yang R: Tumor necrosis factor-like weak inducer of apoptosis accelerates the progression of renal fibrosis in lupus nephritis by activating SMAD and p38 MAPK in TGF- $\beta 1$ signaling pathway. Mediators Inflamm 2016: 1-13, 2016.

28. Christopher-Stine L, Petri M, Astor BC and Fine D: Urine protein-to-creatinine ratio is a reliable measure of proteinuria in lupus nephritis. J Rheumatol 31: 1557-1559, 2004.

29. Wang Q, Sun P, Wang R and Zhao X. Therapeutic effect of dendrobium candidum on lupus nephritis in mice. Pharmacogn Mag 13: 129-135, 2017. 
30. Fenton K, Fismen S, Hedberg A, Seredkina N, Fenton C, Mortensen ES and Rekvig OP: Anti-dsDNA antibodies promote initiation, and acquired loss of renal Dnase1 promotes progression of lupus nephritis in autoimmune (NZBxNZW)F1 mice. PLoS One 4: e8474, 2009.

31. Chen Z, Wang GS, Wang GH and Li XP: Anti-Clq antibody is a valuable biological marker for prediction of renal pathological characteristics in lupus nephritis. Clin Rheumatol 31: 1323-1329, 2012.

32. Li H and Ding G: Elevated serum inflammatory cytokines in lupus nephritis patients, in association with promoted hsa-miR-125a. Clin Lab 62: 631-638, 2016.

33. Wang Q, Sun P, Wang R and Zhao X: Therapeutic effect of Dendrobium candidum on lupus nephritis in mice. Pharmacogn Mag 13: 129-135, 2017.

34. Jin O, Hou CC, Li XQ, Zhang X, Qiu M, Lin D, Fang L, Guo X, Lin Z, Liao Z, et al: THU0274 upregulation of NOD2 involved in the inflammatory response by activation of MAPK signaling pathway in lupus nephritis. Annals of the Rheumatic Diseases 75: 282-286, 2016

35. Zheng CZ, Shu YB, Luo YL and Luo J: The role of miR-146a in modulating TRAF6-induced inflammation during lupus nephritis. Eur Rev Med Pharmacol Sci 21: 1041-1048, 2017.

36. Saitoh A, Ikoma M, Kamiyama C, Doi $K$ and Koitabashi Y: Investigation of CD68 positive monocytes/ macrophage(CD68+ Mo/M phi) in urine and infiltrated tissue of various kidney diseases in children. Nihon Jinzo Gakkai Shi 44: 798-805, 2002 (In Japanese).

37. Ma R, Jiang W, Li Z, Sun Y and Wei Z: Intrarenal macrophage infiltration induced by $T$ cells is associated with podocyte injury in lupus nephritis patients. Lupus 25: 1577-1586, 2016.

38. Wong CY, Cheong SK, Mok PL and Leong CF: Differentiation of human mesenchymal stem cells into mesangial cells in post-glomerular injury murine model. Pathology 40: 52-57, 2008.
39. Schlöndorff D and Banas B: The mesangial cell revisited: No cell is an island. J Am Soc Nephrol 20: 1179-1187, 2009.

40. Liu J, Zhu L, Xie GL, Bao JF and Yu Q: Let-7 miRNAs modulate the activation of NF- $\mathrm{KB}$ by targeting TNFAIP3 and are involved in the pathogenesis of lupus nephritis. PLoS One 10: e0121256, 2015.

41. Huang F, Zhang RY and Song L: Beneficial effect of magnolol on lupus nephritis in MRL/lpr mice by attenuating the NLRP3 inflammasome and NF- $\kappa$ B signaling pathway: A mechanistic analysis. Mol Med Rep 16: 4817-4822, 2017.

42. Geng C, Li J, Ding F, Wu G, Yang Q, Sun Y, Zhang Z, Dong T and Tian X: Curcumin suppresses 4-hydroxytamoxifen resistance in breast cancer cells by targeting SLUG/Hexokinase 2 pathway. Biochem Biophys Res Commun 473: 147-153, 2016.

43. Soetikno V, Sari FR, Veeraveedu PT, Thandavarayan RA, Harima M, Sukumaran V, Lakshmanan AP, Suzuki K, Kawachi $\mathrm{H}$ and Watanabe $\mathrm{K}$ : Curcumin ameliorates macrophage infiltration by inhibiting NF- $\mathrm{BB}$ activation and proinflammatory cytokines in streptozotocin induced-diabetic nephropathy. Nutr Metab (Lond) 8: 35-35, 2011.

44. Zhang L, Pang S, Deng B, Qian L, Chen J, Zou J, Zheng J, Yang L, Zhang C, Chen X, et al: High glucose induces renal mesangial cell proliferation and fibronectin expression through $\mathrm{JNK} / \mathrm{NF}-\kappa \mathrm{B} / \mathrm{NADPH}$ oxidase/ROS pathway, which is inhibited by resveratrol. Int J Biochem Cell Biol 44: 629-638, 2012.

45. Korashy HM and El-Kadi AOS: The role of redox-sensitive transcription factors NF- $\mathrm{KB}$ and $\mathrm{AP}-1$ in the modulation of the Cypla1 gene by mercury, lead, and copper. Free Radic Biol Med 44: 795-806, 2008

46. Wilson PC, Kashgarian M and Moeckel G: Interstitial inflammation and interstitial fibrosis and tubular atrophy predict renal survival in lupus nephritis. Clin Kidney J 11: 207-218, 2018. 